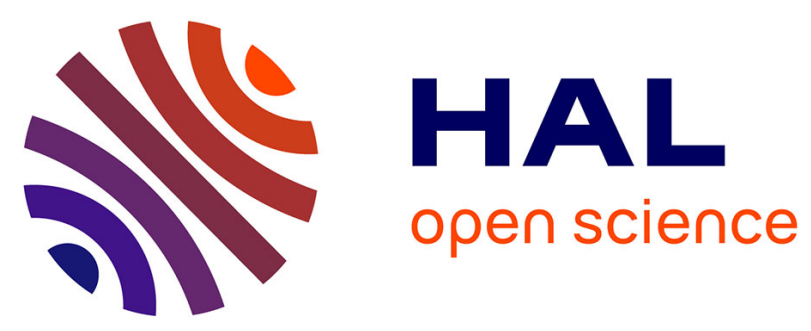

\title{
Changes in ochratoxin A and type B trichothecenes contained in wheat flour during dough fermentation and bread baking processes
}

\author{
Francisco M. Valle-Algarra, Eva M. Mateo, Angel Medina-Vayá, Fernando \\ Mateo, Jose Vicente Gimeno-Adelantado, Misericordia Jiménez
}

\section{To cite this version:}

Francisco M. Valle-Algarra, Eva M. Mateo, Angel Medina-Vayá, Fernando Mateo, Jose Vicente Gimeno-Adelantado, et al.. Changes in ochratoxin A and type B trichothecenes contained in wheat flour during dough fermentation and bread baking processes. Food Additives and Contaminants, 2009, 26 (06), pp.896-906. 10.1080/02652030902788938 . hal-00577363

\section{HAL Id: hal-00577363 https://hal.science/hal-00577363}

Submitted on 17 Mar 2011

HAL is a multi-disciplinary open access archive for the deposit and dissemination of scientific research documents, whether they are published or not. The documents may come from teaching and research institutions in France or abroad, or from public or private research centers.
L'archive ouverte pluridisciplinaire HAL, est destinée au dépôt et à la diffusion de documents scientifiques de niveau recherche, publiés ou non, émanant des établissements d'enseignement et de recherche français ou étrangers, des laboratoires publics ou privés. 


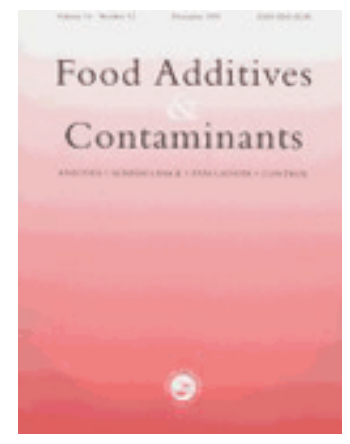

\section{Changes in ochratoxin A and type B trichothecenes contained in wheat flour during dough fermentation and bread baking processes}

\begin{tabular}{|r|l|}
\hline Journal: & Food Additives and Contaminants \\
\hline Manuscript ID: & TFAC-2008-287.R1 \\
\hline Manuscript Type: & Original Research Paper \\
\hline Date Submitted by the & 09-Jan-2009 \\
\hline Complete List of Authors: & $\begin{array}{l}\text { Valle-Algarra, Francisco M.; University of Valencia, Dpt. Analytical } \\
\text { Chemistry } \\
\text { Mateo, Eva; University of Valencia, Dpt. Microbiology and Ecology } \\
\text { Medina-Vayá, Angel; University of Valencia., Microbiology and } \\
\text { Ecology } \\
\text { Mateo, Fernando; Universidad Politécnica de Valencia, Dpt. } \\
\text { Ingenieria Electrónica } \\
\text { Gimeno-Adelantado, Jose Vicente; University of Valencia, Analytical } \\
\text { Chemistry } \\
\text { Jiménez, Misericordia; University of Valencia, Microbioloby and } \\
\text { Ecology }\end{array}$ \\
\hline Food Types: & Bread \\
\hline Additives/Contaminants: & Mycotoxins - trichothecenes, Mycotoxins - ochratoxin A \\
\hline \hline
\end{tabular}

\section{SCHOLARONE ${ }^{\text {m }}$ \\ Manuscripts}




\section{Changes in ochratoxin A and type B trichothecenes contained in wheat}

\section{flour during dough fermentation and bread-baking}

F.M. Valle-Algarra ${ }^{\mathrm{a}}$, E.M. Mateo ${ }^{\mathrm{b}}$, Á. Medina $^{\mathrm{b}}$, F. Mateo $^{\mathrm{c}}$, J.V. Gimeno-Adelantado ${ }^{\mathrm{a}}$, M. Jiménez, ${ }^{\mathrm{b}, *}$

${ }^{a}$ Dpto. de Química Analítica, Facultad de Química, Universidad de Valencia, Dr. Moliner 50, E-46100 Burjassot, Valencia, Spain.

${ }^{b}$ Dpto. de Microbiología y Ecología, Facultad de Biología, Universidad de Valencia, Dr. Moliner 50, E-46100 Burjassot, Valencia, Spain.

${ }^{c}$ Dpto. de Ingeniería Electrónica, Universidad Politécnica de Valencia, Camino de Vera 14, E-46022, Valencia, Spain.

\section{Abstract}

Ochratoxin A (OTA) and type B trichothecenes are mycotoxins that occur frequently in cereals and thus can be found in cereal by-products such as bread. The aim of this work was to study the variation of the levels of OTA, deoxynivalenol (DON), 3-acetyldeoxynivalenol (3-ADON) and nivalenol (NIV) during the bread making process. This was done using wheat flour spiked with different levels of toxins. Mycotoxin levels were controlled after fermentation of the dough with yeasts (Saccharomyces cerevisiae) and after further baking at different temperature/time combinations. ANOVA of the results showed a significant reduction in OTA level $(\mathrm{p}<0.05)$ during fermentation of the dough. The reduction ranged between $29.8 \%$ and $33.5 \%$, depending on the initial concentration of toxin in the flour. During this period the level of the other mycotoxins studied was not modified. By contrast, in the baking phase there were significant changes in the levels of the four mycotoxins, although the reduction was similar under all the baking conditions. Considering all the temperature/time conditions tested, it can be concluded that during the baking period the average reduction of OTA, NIV, 3-ADON, and DON was 32.9\%, 76.9\%, 65.6\%, and $47.9 \%$, respectively.

Keywords: fermented dough, wheat flour, mycotoxin reduction, baking process.

*Corresponding autor: E-mail: misericordia.jimenez@uv.es Fax:+963544570 


\section{Introduction}

3

4

Food such as cereals, are susceptible to be contaminated with mycotoxins (Scott et al. 1984, Samar et al. 2003). Mycotoxin-producing fungi are mainly Fusarium spp., Aspergillus spp. and Penicillium spp., which are frequently isolated from the whole kernel (González et al. 1996, González et al. 1999, Medina et al. 2006a). It has been demonstrated that different cereals by-products of massive consumption in Europe and other countries, like bakery products and beer, are often contaminated with ochratoxin A (OTA) and trichothecenes (Quiroga et al. 1995, Pacin et al. 1997, Moltó et al. 2000, Samar et al. 2001, Medina et al. 2006b).

OTA formation presents a risk in cereals because grain is often harvested at high moisture contents, sometimes above 20\%. Drying is often necessary to prevent the development of storage moulds, such as Penicillium verrucosum, Aspergillus ochraceus and Aspergillus section Nigri, species considered to be the usual OTA producers in cereals (Frisvad and Lund 1993, Valero et al. 2006). However, this procedure is sometimes not carried out quickly enough or the cereals are not dried sufficiently for safe, long-term storage.

OTA has been found to be a potent renal toxin in all of the animal species tested. It induces a typical karyomegaly and a progressive nephropathy. Previous National Toxicology Program studies in United States showed that OTA can induce renal tumours in rodents at high dosages (EFSA 2006).

Type B trichothecenes, produced by some Fusarium species such as $F$. graminearum and F. culmorum (Llorens et al. 2004) are frequent contaminants of cereal crops worldwide (Scott 1989, 1996). They affect animal and human health and present various toxicological characteristics, such as skin irritability, hemorrhagic syndrome, decrease in bone marrow, depression, diarrhoea, nausea, feed refusal and vomiting. They can inhibit protein synthesis, alter brain neurochemicals and may be immunosuppressive (Ueno 1983, Tryphonas et al. 1984, Pacin 1992, Rotter et al. 1996, Sugita-Konishi et al. 1998). The WHO presented a comparative estimate of human exposure in Europe, the Far East, Latin America and the Middle East. This comparison demonstrated that in Europe, approximately $80 \%$ of the total deoxynivalenol (DON) intake is associated with the consumption of wheat, whereas in the Far East, wheat and rice are equally important as source of DON exposure (WHO 1998, FAO/WHO 2001b). 
In the last few years, different international committees considered the question about 2 risk assessment and tolerable daily intake (TDI) of OTA and trichothecenes [Eriksen and 3 Alexander 1998, Scientific Committee on Food (SCF) 1999, 2000, FAO/WHO 2001a]. In 4 case of OTA, the FAO/WHO (2001a) retained the previously established Provisional 5 Tolerable Weekly Intake of $100 \mathrm{ng} \mathrm{kg}^{-1}$ body weight (b.w.) per week. The European Food Safety Authority (EFSA) recommended a Tolerable Weekly Intake of $120 \mathrm{ng} \mathrm{kg}^{-1}$ b.w. per week for OTA (EFSA 2006). In Europe, the SCF $(1999,2002)$ and the recent SCOOP task (Gareis et al. 2003) have concluded that an exposure of consumers close to the TDI of 1 and $0.7 \mu \mathrm{g} \mathrm{kg}^{-1}$ b.w. day ${ }^{-1}$ for DON and nivalenol (NIV), respectively, is possible (Samar et al. 2007).

The European Commission (EC) has recently established maximum levels in cereals intended for direct human consumption to reduce the risk to the consumer for OTA and DON, which are $3 \mu \mathrm{g} \mathrm{kg}^{-1}$ and $750 \mu \mathrm{g} \mathrm{kg}^{-1}$, respectively (Commission Regulation 2006).

Dietary exposure to OTA and type B trichothecenes varies considerably depending on different factors, among which food-processing systems must be considered. These systems are often traditional and characteristic of the different geographical regions and, up to date, their influence on the mycotoxin content of the food finished products ready for consumption has been scarcely studied.

Thus, an effective treatment for eliminating these mycotoxins from cereal products is essential to minimize human exposure to the toxins. The results from the literature suggest that during food processing (cleaning, milling, baking), fractionation or reduction occurs (Abbas et al. 1985, Charmley and Prelusky 1994, Schollenberger et al. 2005, Bullerman and Bianchini 2007). Some physical and chemical methods have been used to reduce mycotoxin contamination of foodstuffs and feedstuffs. These methods include segregation of contaminated from non-contaminated kernels in water and saturated sodium chloride, milling, cleaning or washing, sieving and dehulling (Scott 1991, Trenholm et al. 1991).

Few studies have been carried out on the reduction of OTA during bakery processing (El-Banna and Scott 1984, Osborne et al. 1996, Scudamore et al. 2003). It has been reported that temperatures above $250^{\circ} \mathrm{C}$ applied during several minutes are required to reduce OTA concentration (Boudra et al. 1995), and that under certain conditions of high temperature, acidic or alkaline conditions or in the presence of enzymes breakdown can occur (Baxter 1996, Scott 1996, Scudamore 1996, Subirade 1996).

In the case of DON, reports have shown that boiling could be expected to be an effective means of reducing the toxin level because the secondary metabolite is water-soluble 
1 (Sugita-Konishi et al. 2006, Ragab et al. 2007). In other study, the presence of DON in the 2 different steps of the manufacture of turnover pie dough covers prepared for baking and for 3 frying was studied with the objective to evaluate the industrial processing effect on DON 4 reduction (Del Pelo 2002, Samar et al. 2007).

DON has been reported to be highly stable to bakery processes due to its thermal stability (El Banna et al. 1983, Young et al. 1986, Scott 1991, Boyacioglu et al. 1993, Neira et al. 1997) On the other hand, other authors have reported that bakery processing reduce DON contamination (Neira et al. 1997, Samar et al. 2001, 2007). The effects of various food additives, such as oxidizing (potassium bromate) and reducing (sodium hydrogensulfite, Lcysteine and L-ascorbic acid) agents, and ammonium phosphate, at varying levels, on DON in whole wheat flour during breadbaking were also investigated. Fermentation of the dough, sodium hydrogensulfite and L-cysteine and ammonium phosphate were moderately effective in reducing DON level in bread (Young et al. 1986, Young 1986, Boyacioglu et al. 1993).

Due to the culinary customs and considering that appreciable amounts of wheat based foods, among which bread must be highlighted, are consumed worldwide, it is important to establish how processes such as baking can reduce the contamination by OTA and trichothecenes B in bread ready to be consumed. This research is complicated because baking is a handmade process characteristic of each geographic region and the levels of mycotoxins in the wheat used in each region are also different.

The aim of this study was to evaluate how the different bread making conditions usual in Spain affect the levels of OTA, DON, NIV and 3-acetyldeoxynivalenol (3-ADON) that occur initially in the wheat flour used to make bread.

Materials and methods

\section{Chemicals and reagents}

OTA and trichothecene standards, including NIV, DON, and 3-ADON were supplied 28 by Sigma (Sigma-Aldrich, Alcobendas, Spain). Toluene and sodium hydrogen carbonate 29 were from Panreac (Montcada i Reixac, Barcelona, Spain). Acetonitrile, methanol, were from 30 J.T. Baker (Deventer, Holland). All solvents were HPLC grade. Standardized 70-230 mesh 31 aluminium oxide 90 (0.063-0.2 mm particle size) was purchased from Merck (Darmstadt, 32 Germany). Activated charcoal (Norit) was from Fluka (Sigma-Aldrich). Glass microfibre 33 filters (GF/C) and filter papers (Whatman No 4) were from Whatman (Maidstone, UK). 34 Pentafluoropropionic anhydride (PFPA) and 4-dimethylaminopyridine (DMAP) were also 
1 from Sigma. $\mathrm{C}_{18}$-silica was from Waters (Milford, MA, USA). Immunoaffinity clean-up 2 columns (OchraTest ${ }^{\mathrm{TM}}$ ) were purchased to Vicam (Vicam Science Technology, MA, USA). 3 Phosphate-buffered saline (PBS) was prepared with potassium chloride (0.2 g, Panreac), 4 potassium dihydrogen phosphate ( $0.2 \mathrm{~g}$, Sigma), anhydrous disodium hydrogen phosphate 5 (1.16 g, Panreac) and sodium chloride (8.0 g, J.T. Baker) in 11 of pure water; the pH was brought to 7.4. Pure water was obtained from a Milli-Q apparatus (Millipore, Billerica, MA, USA) and was used when water was required. Compressed yeast cake was purchased in a

9 local bakery and was stored at $4{ }^{\circ} \mathrm{C}$.

\section{Preparation of standard solutions}

A stock solution of OTA was prepared by solving $1 \mathrm{mg}$ of OTA in $2 \mathrm{ml}$ of tolueneacetic acid (99:1, v/v) and stored at $-20^{\circ} \mathrm{C}$ in a sealed vial until use. Working standards (100, 25.0, 10.0, 5.0, 1.0, 0.5, 0.2, 0.1, $0.05 \mathrm{ng} \mathrm{ml}^{-1}$ ) was prepared by evaporation of known aliquots of the stock solution and dissolution in filtered LC mobile phase.

Each standard of NIV, DON and 3-ADON was dissolved in acetonitrile at a concentration of $1.0 \mathrm{mg} / \mathrm{ml}$ and stored at $-20^{\circ} \mathrm{C}$ in a sealed vial until use. Working standards $\left(500,100,25,10.0,2.0,1.0,0.5,0.25,0.1,0.05\right.$ and $0.02 \mu \mathrm{g} \mathrm{ml}^{-1}$ ) were prepared by appropriate dilution of known volumes of the stock solution with acetonitrile.

\section{Spiking process}

The wheat flour batch used in the experiments was obtained from the retail market. It was previously analyzed for OTA and trichothecenes and found to contain these toxins below the limits of detection of the methods used in this work. Part of the wheat flour was contaminated with 2,5 , and $10 \mu \mathrm{g}$ of OTA kg ${ }^{-1}, 200,750$, and $1500 \mu \mathrm{g}$ of both DON and 3ADON kg${ }^{-1}$, and 200, 500 and $1000 \mu \mathrm{g}$ of NIV kg-1 by addition of the appropriate volumes of standard solutions of the mycotoxins. These levels fell within the linear range of the calibration lines. Sample handling was carried out in a hood and laboratory glasses, masks and gloves were worn for safety purposes. After being spiked, each portion of contaminated flour was thoroughly homogenized and used to prepare the dough once the mycotoxin solvents were evaporated. Three combinations were assayed: a) $2 \mu \mathrm{g}$ of OTA kg${ }^{-1}, 200 \mu \mathrm{g}$ of DON kg${ }^{-1}, 200 \mu \mathrm{g}$ of $3-\mathrm{ADON} \mathrm{kg}^{-1}$ and $200 \mu \mathrm{g}$ of NIV kg${ }^{-1}$; b) $5 \mu \mathrm{g}$ of OTA kg${ }^{-1}, 750 \mu \mathrm{g}$ of DON kg-1 $750 \mu \mathrm{g}$ of $3-\mathrm{ADON} \mathrm{kg}^{-1}$ and $500 \mu \mathrm{g}$ of NIV kg-1; and c) $10 \mu \mathrm{g}$ of OTA $\mathrm{kg}^{-1}$, $1500 \mu \mathrm{g}$ of DON kg${ }^{-1}, 1500 \mu \mathrm{g}$ of $3-\mathrm{ADON} \mathrm{kg}^{-1}$ and $1000 \mu \mathrm{g}$ of NIV kg${ }^{-1}$. These spiked 
1 samples were analyzed before fermentation and the levels were consistent with the recovery 2 rates found for the method.

3

4

5

6

\section{Dough preparation and bread making}

Dough was made with mycotoxin-spiked wheat flour, compressed yeast cake, water and sodium chloride. (50:2:30:1, w/w/v/w). Firstly, flour was mixed with sodium chloride then, moistened with water and, finally, yeast cake (suspended in water) was incorporated. Dough was manually mixed until held together with a non-sticky, smooth and satiny appearance and optimum handling properties.

Rounded pieces of about $8 \mathrm{~cm}$ diameter each weighing $80 \mathrm{~g}$ were prepared. They were covered with a damp cloth and fermentation was carried out at $29-30{ }^{\circ} \mathrm{C}$, for 1 hour.

After fermentation, dough was baked in a muffle furnace (Gallur, Valencia, Spain) at $190,207,223$, and $240^{\circ} \mathrm{C}$ for $50,40,35$ and $30 \mathrm{~min}$, respectively. These conditions were established on the basis of previous experiments to obtain well-baked bread. After baking, bread pieces were stored at $-20^{\circ} \mathrm{C}$ until determination of the mycotoxins.

The baking process to obtain bread was repeated under the same temperature-time conditions previously indicated, but now each piece of bread was separated in two portions, the inner part and the outer part (or crust) and both parts were stored at $-20^{\circ} \mathrm{C}$ until analysis.

At each mycotoxin-spiking level, dough fermentation and baking for analysis of the whole piece or the inner/outer part of bread were performed in triplicate.

\section{Extraction and clean-up for OTA}

Extraction and clean-up was performed according to the Vicam technical note and suggestions for the analysis of wheat (Vicam 1999) with slight modifications. Bread was finely ground using an IKA A10 laboratory mill (IKA, Stauffen, Germany) and homogenized. Seven and half grams of ground bread or dough (was extracted with $25 \mathrm{ml}$ of acetonitrile/water (60:40, v/v) in a high-speed blender (Ultraturrax T25, IKA) for $5 \mathrm{~min}$. The suspension was centrifuged at $6000 \mathrm{rpm}$ for $6 \mathrm{~min}$ at $4{ }^{\circ} \mathrm{C}$ (Heraeus Multifuge $1 \mathrm{~s}$-r, Hanau, Germany). Supernatant $(10 \mathrm{ml})$ was diluted with $40 \mathrm{ml}$ of pure water. Diluted solution $(10 \mathrm{ml})$ was loaded into the immunoaffinity column and passed at a flow rate at 1-2 drops/s. The column was washed sequentially with $10 \mathrm{ml}$ of PBS and $10 \mathrm{ml}$ of pure water. Then, it was eluted with $1.5 \mathrm{ml}$ of methanol at a rate of about $1 \mathrm{drop} / \mathrm{s}$ in a 4-ml vial. The purified extract was concentrated to dryness at $45^{\circ} \mathrm{C}$ under gentle stream of nitrogen and solved in $0.5 \mathrm{ml}$ of LC mobile phase. 


\section{Liquid chromatographic analysis of OTA}

3

4

The LC system consisted of a Waters 600 pump, a Waters 717 automatic injector and a Waters 474 scanning fluorescence detector (FLD). Millennium 32 software, version 3.05.01 (Waters Co., Milford, MA, USA) was used to control the system and to process signals. LCFLD conditions were used as described by Medina et al. (2005).

The solution $(100 \mu \mathrm{l})$ was injected into the liquid chromatograph. Separation was performed on a Gemini C18 column $(150 \mathrm{~mm} \times 4.6 \mathrm{~mm}, 5 \mu \mathrm{m}$ particle size $)$ connected to a Gemini guard column (12.5 mm×4.6 mm, $5 \mu \mathrm{m}$ particle size) (Phenomenex Inc., Torrance, CA, USA) filled with the same phase. The column was kept at $40{ }^{\circ} \mathrm{C}$. A mixture of acetonitrile-water-acetic acid (44:56:1, v/v/v) at $1.0 \mathrm{ml} / \mathrm{min}$ flow-rate was used as mobile phase. Quantification of OTA was performed by measuring its peak area with the help of a calibration curve calculated by regression from standard solutions. Excitation and emission wavelengths were 333 and $460 \mathrm{~nm}$, respectively. Five injections per extract were performed and the average concentration was used for calculations.

The limit of detection (LOD) for OTA in ground bread was $0.015 \mu \mathrm{g} \mathrm{kg}^{-1}$ (Signal-to noise ratio $=3$ ). The limit of quantification (LOQ) was considered to be 3 times the LOD. Recovery in ground bread contaminated with $5 \mu \mathrm{g}$ of OTA $\mathrm{kg}^{-1}$ was $78 \% \pm 5 \%(\mathrm{n}=3)$.

\section{Extraction and SPE clean-up for trichothecenes}

Extraction and clean-up for trichothecenes were performed as described by ValleAlgarra et al. (2005). Five grams of dough or milled bread sample was poured into a 100-ml Erlenmeyer flask. After adding $40 \mathrm{ml}$ of acetonitrile-water $(84: 16$, v/v), the mixture was blended in a high-speed blender for $10 \mathrm{~min}$. After filtering through Whatman No. 4 filter, the extraction mixture was stored in a tightly closed glass bottle at $-20{ }^{\circ} \mathrm{C}$ until use.

Made-in-laboratory cartridges were prepared using 5-ml sterile plastic syringes. A glass microfibre filter was placed at the bottom. Then, a mixture of packing bed was poured on it. It was made of $1.16 \mathrm{~g}$ of alumina-charcoal-C18 silica (75:1:40, w/w/w). Another glass microfibre filter was placed on the bed top. Then, it was pressed tightly but carefully with a plunger. Three $\mathrm{ml}$ of sample extract was passed through the prepared cartridge and collected in a vial. The cartridge was rinsed with $2 \mathrm{ml}$ of acetonitrile-water $(84: 16, \mathrm{v} / \mathrm{v})$. The eluate was collected in the same vial and the purified extract was concentrated to dryness at $45{ }^{\circ} \mathrm{C}$ under gentle stream of nitrogen. 


\section{Derivatization for GC-ECD determination for trichothecenes}

A $2 \mathrm{mg} / \mathrm{ml}$ solution of DMAP $(100 \mu \mathrm{l})$ in toluene-acetonitrile (80:20, v/v) and $50 \mu \mathrm{l}$ of PFPA were added to each dry extract in a screw cap vial. After capping tightly, the reaction mixture was heated at $60{ }^{\circ} \mathrm{C}$ for $60 \mathrm{~min}$ in aluminium heater block (Lab-Line 2050-1 MultiBlock Heater, Melrose Park, IL, USA). After the mixture had cooled, $0.4 \mathrm{ml}$ toluene and $1 \mathrm{ml}$ of a $3 \%(w / v)$ aqueous solution of $\mathrm{NaHCO}_{3}$ were added and the vial was vortexed for $15 \mathrm{~s}$. The two layers were allowed to separate. The top (organic phase) layer was transferred to a GC autoinjector vial and analyzed by GC-ECD.

\section{GC-ECD analysis of trichothecenes}

The GC system was composed of a HP-6890 Plus gas chromatograph, equipped with a ${ }^{63} \mathrm{Ni}$ ECD (Hewlett-Packard, Avondale, PA, USA) and an Agilent 7683 Series injector (Agilent Technologies, Waldbronn, Germany). Signals were processed by HP GC ChemStation software Version A.07:01(682) (Hewlett-Packard).

The solution $(1 \mu \mathrm{l})$ was injected in splitless mode. The temperatures of the injection and detection ports were 250 and $300{ }^{\circ} \mathrm{C}$, respectively. Separation was carried out in a HP-5 fused-silica capillary column [5\% methyl phenyl siloxane $(30 \mathrm{~m} \times 0.32 \mathrm{~mm}$ i.d., $0.25 \mu \mathrm{m}$ film thickness, Agilent Technologies)]. The oven temperature program was: $90{ }^{\circ} \mathrm{C}$ held for $1 \mathrm{~min}$, $40{ }^{\circ} \mathrm{C} / \mathrm{min}$ to $160^{\circ} \mathrm{C}, 1.5^{\circ} \mathrm{C} / \mathrm{min}$ to $182^{\circ} \mathrm{C}, 5^{\circ} \mathrm{C} / \mathrm{min}$ to $240{ }^{\circ} \mathrm{C}$, and then $40^{\circ} \mathrm{C} / \mathrm{min}$ to $275^{\circ} \mathrm{C}$, held for $2 \mathrm{~min}$. Helium at a constant pressure of $42.1 \mathrm{kPa}$ was used as carrier gas.

LODs for DON, NIV and 3-ADON were $8 \mu \mathrm{g} \mathrm{kg}^{-1}, 15 \mu \mathrm{g} \mathrm{kg}^{-1}$ and $11 \mu \mathrm{g} \mathrm{kg}^{-1}$, respectively (signal-to-noise ratio $=3$ ). The limit of quantification (LOQ) was considered to be 3 times the LOD. Recoveries of DON, NIV and 3-ADON, added to milled bread at a level of $500 \mu \mathrm{g}$ of each trichothecene $\mathrm{kg}^{-1}$ and expressed as percentages, were $76 \pm 8,86 \pm 9$ and 77 \pm 8 , respectively.

\section{Results and discussion}

The effect of different baking conditions on the levels of OTA, DON, NIV, and 3ADON present in the flour used to bake bread has been studied. The results indicate that during dough fermentation a significant reduction $(\mathrm{p}<0.05)$ of the OTA level takes place, which ranged from $29.8 \%$ to $33.5 \%$, depending on the OTA amount added to the what flour (Figure 1). Some authors (Cecchini et al. 2006) have reported that during alcoholic fermentation of wine, OTA level in the medium decreases significantly. However, Scudamore 
1 et al. (2003) did not find toxin reduction during dough fermentation. It has been found that 2 OTA reduction during fermentation caused by yeasts is dependent on the particular strain 3 involved in fermentation (Cecchini et al. 2006, Westby et al. 1997), which could explain the controversial results reported by different authors. Therefore, it is important to highlight that, on the basis of the results obtained in our work and those from other researchers, the use of yeasts selected in industrial fermentations could be an excellent tool to control OTA in food and beverages that are common in diet, like bread, beer and wine, where a high occurrence of OTA has been reported (González-Osnaya et al. 2007, Mateo et al. 2007).

Under the conditions employed in the present study, fermentation does not decrease the level of any of the assayed trichothecenes. Although very few papers concerning this topic appear in the literature, some authors have analyzed the effect of fermentation on the level of DON in Egyptian bread (El Banna et al. 1983) and in French bread and bridge roll (Samar et al. 2001). None of these studies showed a reduction of DON in dough during fermentation at $30{ }^{\circ} \mathrm{C}$, the temperature commonly used for fermentation in bread making. However, it was found that a significant reduction of the DON level in the fermented dough of a bridge roll took place if fermentation was performed at $50{ }^{\circ} \mathrm{C}$ during periods of 60 min (Samar et al. 2001). Studies on the effect of fermentation on the stability of type B trichothecenes in bread dough and other matrices are necessary to determine under what conditions this process could be effective as a tool to eliminate this mycotoxin from fermented by-products ready for consumption such as bread and beer, a beverage where DON has been detected (Anselme et al. 2006).

The effect of fermentation on 3-ADON and NIV levels in bread dough has been studied in this present work for the first time. Figure 1 shows that fermentation of the dough does not affect the level of any of these trichothecenes under the tested conditions.

After fermentation, the bread was baked at different temperature/time combinations $\left(190{ }^{\circ} \mathrm{C} / 50 \mathrm{~min}, 207^{\circ} \mathrm{C} / 40 \mathrm{~min}, 223^{\circ} \mathrm{C} / 35 \mathrm{~min}\right.$ and $240{ }^{\circ} \mathrm{C} / 30 \mathrm{~min}$ ). These baking conditions were chosen because they are commonly used in bread production in Spain. The results for the reduction percentage and standard deviation of the different toxins under the tested baking conditions are shown in Figure 2. ANOVA of the data showed no significant differences ( $p>$ $0.05)$ in the reduction percentages of each toxin in relation to the temperature/time combination used, but there were significant differences $(\mathrm{p}<0.05)$ among the different mycotoxins. The average reduction percentages for NIV, 3-ADON, DON and OTA during baking were $76.9 \%, 65.6 \%, 47.9 \%$ and $32.9 \%$, respectively. Reduction rate during fermentation was calculated as the percentage of decrease in toxin content during 
1 fermentation with respect to the initial toxin level in wheat flour. Reduction rate during the 2 whole process was calculated in the same way but in this case the decrease refers to the final 3 toxin content (after bread baking). The difference between the latter and the former is the 4 reduction rate due only to the baking process.

OTA reduction rate was higher than that detected by other authors (Scudamore et al. 2003, Osborne et al. 1996), especially if the process is considered as a whole (fermentation plus baking) and was lower than that detected by Boudra et al. (1995). These authors tested treatments of $200^{\circ} \mathrm{C} / 24$ minutes, $200^{\circ} \mathrm{C} / 48 \mathrm{~min}$ and $250^{\circ} \mathrm{C} / 16 \mathrm{~min}$, and detected OTA reductions in wheat flour of $80 \%, 94 \%$ and $88 \%$, respectively.

Conflicting results have been obtained by different authors for the percentage reduction in DON during the bread making process. Some authors (Tanaka et al. 1986, Scott et al. 1983, Sugita-Konishi et al. 2006) detected no significant reductions whereas Abbas et al. 13 (1985) and Neira et al. (1997) found reduction rates ranging from 19.1-69.4\% and 16.8\%$1496.6 \%$, respectively. According to $\mathrm{FAO} / \mathrm{WHO}$ (2001b) trichothecenes are stable at $120^{\circ} \mathrm{C}$, 15 moderately stable at $180^{\circ} \mathrm{C}$ and decompose within $30-40$ min at $210^{\circ} \mathrm{C}$. In this study, a 16 reduction rate of $48.6 \%$ was found during baking but not during fermentation. As noted above, this is the first study to examine NIV and 3-ADON stability during baking. The results show that of the four mycotoxins tested, NIV and 3-ADON show the greatest reduction rate during the process under the conditions used.

20 In addition to temperature, other factors, such as the strain of yeast used in the 21 fermentation, baking time, bread size, etc, influence the bread making process and can 22 influence the stability of the studied mycotoxins.

The European Union has set up maximum levels for OTA and DON in cereals for human consumption of $3 \mu \mathrm{g} \mathrm{kg}^{-1}$ and $750 \mu \mathrm{g} \mathrm{kg}^{-1}$, respectively (European Commission 2006). Moreover, it has been established in Europe that exposure of consumers close to the TDI of 1 $\mu \mathrm{g} \mathrm{kg}-1$ body weight per day for DON and to the Tolerable Weekly Intake of $120 \mathrm{ng} \mathrm{kg}^{-1}$ body weight per week for OTA is possible (Gareis et al. 2003, EFSA 2006, Samar et al. 2007). To reach these values, for a person of $70 \mathrm{~kg}$ weight it would be necessary an intake of $8.4 \mu \mathrm{g}$ of OTA per week and $70 \mu \mathrm{g}$ of DON per day. Taking into account that during baking average reduction rates of OTA and DON are 60 and 48\%, respectively, the maximum levels cited above will be reduced during the baking process to $1.2 \mu \mathrm{g}$ OTA and $390 \mu \mathrm{g}$ DON per $\mathrm{kg}$ of wheat flour. To reach the tolerable intakes, a person of $70 \mathrm{~kg}$ weight must consume in the 33 form of bread $7000 \mathrm{~g}$ of wheat flour contaminated at the maximum levels per week in the case of OTA and $179 \mathrm{~g}$ of wheat flour per day in the case of DON. The European Union has 
1 established maximum levels of $500 \mu \mathrm{g}$ of $\mathrm{DON} \mathrm{kg}^{-1}$ in bread (including small bakery wares),

2 pastries, biscuits, cereal snacks and breakfast cereals, which limits the daily consumption of 3 bread to a maximum of $140 \mathrm{~g}$. It is then possible to exceed the TDI for DON under the current 4 European Regulation because not only bread but also other products made from cereals that can be contaminated with DON are consumed regularly. Therefore, a revision of the current European Union regulation concerning the maximum levels for these toxins seems to be necessary to protect consumers' health.

In order to examine for differences in the reduction percentage of the different mycotoxins on the inside and outside of the bread, when the baking process finished, samples were taken from the outer part (crust) and the inner part of the pieces of bread and the four mycotoxins were determined in both parts. Figure 3 shows that the decrease in the different mycotoxins was greater in the bread crust than in the centre. ANOVA of the data showed that 13 there were significant differences $(\mathrm{p} \leq 0.05)$ in the stability of the different toxins inside and 14 outside the bread.

The ranges of reduction percentages for OTA, NIV, 3-ADON and DON inside the bread, taking into account all the assayed conditions, were $7.3-38.2,46.4-83.4,42.5-64.7$ and $18.1-62.6 \%$, respectively. In the bread crust the same ranges for OTA, NIV, 3-ADON and DON were 20.4 - 51.3, 72.0 - 93.1, 58.3 - 83.4, and 41.0 - 70.7\%, respectively.

Bread size may have a relevant effect on the level of mycotoxin reduction during baking and may be one of the factors behind the conflicting results reported by different authors.

It is important to take into account the fact that this reduction in mycotoxin level would result in equally reduced harmful effects to health because food processing methods such as heating and boiling can themselves produce new toxic compounds (Bullerman and Ryu 2002, Howard et al. 2002, Yumbe-Guevara and Yoshizawa 2003, Sugita-Konishi et al. 2006). The observed reduction indicates that the product is not detected with the methods employed but does not proof any degradation of the toxins. Binding of toxins to matrix compounds such as proteins or carbohydrates may be possible and bear the risk that during digestion the toxin is released as reported for fumonisins (Humpf and Voss 2004). These are 
1 The authors wish to thank financial support from the Spanish Government "Ministerio 2 de Educación y Ciencia" (Projects AGL-2004-07549-C05-02/ALI and AGL2007-664163 C05-01/ALI and for two research grants) and from the Valencian Government (Conselleria 4 d'Empresa, Universitat i Ciencia) (Project ACOMP/2007/155). Finally, the authors thank Ms 5 Esther Gamero, Ms Teresa Liberia, Ms Gema Garcia, Ms Maria Jose Aparisi, Ms Carmen 6 Garcia, and Ms Elena Sanchis for her technical assistance. 7

8 References

9

10 Abbas HK, Mirocha CJ, Pawlosky RJ, Pusch DJ. 1985. Effect of cleaning, milling and baking 11 on deoxynivalenol in wheat. Appl Environ Microbiol. 50: 482-486. 12

13 Anselme M, Tangni EK, Pussemier L, Motte JC, Van Hove F, Schneider YJ, Van Peteghem 14 C, Larondelle Y. 2006. Comparison of ochratoxin A and deoxynivalenol in organically and 15 conventionally produced beers sold on the Belgian market. Food Addit Cont. 23: 910-918.

16 Baxter ED. 1996. The fate of ochratoxin A during malting and brewing. Food Addit Cont. 17 13(suppl.): 23-24. 18

19 Boudra H, Le Bars P, Le Bars J. 1995. Thermostability of ochratoxin A in wheat under two 20 moisture conditions. Appl Environ Microbiol. 61: 1156-1158. 21

22 Boyacioglu D, Hettierachchy NS, D’Appolonia BL. 1993. Additives affect deoxynivalenol 23 (vomitoxin) flour during breadmaking. J Food Sci. 58: 416-418. 24

25 Bullerman LB, Ryu D. 2002. Stability of fumonisins in food processing. Adv Exp Med Biol. 26 504: 195-204.

28 Bullerman LB, Bianchini A. 2007. Stability of mycotoxins during food processing. Int J Food 29 Microbiol. 119: 140-146.

30

31 Cecchini F, Morassut M, Garcia-Moruno E, Di Stefano R. 2006. Influence of yeast strain on 32 ochratoxin A content during fermentation of white and red must. Food Microbiol. 23: 41133417. 
1 Charmley LL, Prelusky DB. 1994. Mycotoxins in Grain-Compounds other than Aflatoxins.

2 St. Paul (MN, USA): Miller JD, Trenholm HL; Eagan Press. Decontamination of Fusarium 3 mycotoxins, p. 421-435.

4

5 European Commission. 2006. Commission Regulation No 1881/2006 of 19 December 2006 6 setting maximum levels for certain contaminants in foodstuffs. Official Journal of the 7 European Union of 20.12.2006, L 364, p. 5-24.

9 Del Pelo DH. 2002. Modificaciones en el proceso de elaboración de tapas de empanadas 10 tendientes a disminuir el contenido de micotoxinas [Thesis in Food Engineering]. [Luján 11 (Argentina)]: Universidad Nacional de Luján.

EFSA, 2006. Question $N^{\circ}$ EFSA-Q-2005-154. Opinion of the scientific panel on

14 contaminants in the food Chain on a request from the commission related to ochratoxin $\mathrm{A}$ in

15 food. Adopted on 4 April 2006. Available from

16 http://www.efsa.europa.eu/etc/medialib/efsa/science/contam/contam_opinions/1521.Par.0001.

File.dat/contam_op_ej365_ochratoxin_a_food_en1.pdf

El Banna AA, Lau PY, Scott PM. 1983. Fate of mycotoxins during processing of foodstuffs

II- Deoxynivalenol (vomitoxin) during making of Egyptian bread. J Food Prot. 46: 484-486.

El-Banna AA, Scott PM. 1984. Fate of mycotoxins during processing. III. Ochratoxin A during cooking of faba beans (Vicia faba) and polished wheat. J Food Prot. 47: 189-192.

Eriksen GS, Alexander J. 1998. Fusarium toxins in cereals-a risk assessment. Copenhagen (Denmark): TemaNord report 502. Nordic Council of Ministers, vol. 23, p. 28-58.

FAO/WHO (Food and Agriculture Organisation/World Health Organisation). 2001a. 29 Ochratoxin A. Geneva (Switzerland): Safety evaluation of certain mycotoxins in food, 30 Prepared by the 56th Meeting of the Joint FAO/WHO Expert Committee on Food Additives 31 (JECFA). WHO Food Additives Series 47, World Health Organisation, p. 281-387. Available 32 from http://www.inchem.org/documents/jecfa/jecmono/v47je04.htm 
1 FAO/WHO (Food and Agriculture Organisation/World Health Organisation), 2001b.

2 Ochratoxin A. Geneva (Switzerland): Safety evaluation of certain mycotoxins in food, 3 Prepared by the 56th Meeting of the Joint FAO/WHO Expert Committee on Food Additives 4 (JECFA). WHO Food Additives Series 47, World Health Organisation. Available from 5 http://www.inchem.org/documents/jecfa/jecmono/v47je05.htm

6 Frisvad JC, Lund F. 1993. Toxin and secondary metabolite production by Penicillium species. 7 Proceedings of the United Kingdom Workshop on Occurrence and Significance of 8 Mycotoxins. Slough: Central Science Laboratory, MAFF, p. 146-171.

9

10 Gareis M, Schothorst RC, Vidnes A, Bergsten C, Paulsen B, Brera C, Miraglia M. 2003. 11 'SCOOP task 3.2.10. Collection of Occurrence Data of Fusarium Toxins in Food and 12 Assessment of Dietary Intake by the Population of EU Member States'. Available from 13 http://europa.eu.int/comm/food/fs/scoop/task3210.pdf 14

15 González HHL, Martínez EJ, Pacin A, Resnik SL. 1999. Relationship between Fusarium 16 graminearum and Alternaria alternata contamination and deoxynivalenol occurrence on 17 Argentinian durum wheat. Mycopathol. 144: 97-102.

González HHL, Pacin A, Resnik SL, Martínez EJ. 1996. Deoxynivalenol and contaminant 20 mycoflora in freshly harvested Argentinian wheat in 1993. Mycopathol. 135: 129-134.

González-Osnaya L, Soriano JM, Moltó JC, Mañes J. 2007. Dietary intake of ochratoxin A from conventional and organic bread. Int J Food Microbiol. 118: 87-91.

Howard PC, Couch LH, Patton RE, Eppley RM, Doerge DR, Churchwell ML, Marques MM, Okerberg CV. 2002. Comparison of the cytotoxicity of several fumonisin derivatives in a 28 day feeding study with female B6C3F(1) mice. Tox Appl Pharmacol. 185: 153-165.

Humpf H-U, Voss KA. 2004. Effects of thermal food processing on the chemical structure and toxicity of fumonisin mycotoxins. Mol. Nutr. Food Res. 48: 255-269.

Llorens A, Mateo R, Hinojo MJ, Valle-Algarra FM, Jiménez M. 2004. Influence of 33 environmental factors on the biosynthesis of type B trichothecenes by isolates of Fusarium spp. from Spanish crops. Int J Food Microbiol. 94: 43-54. 
2 Mateo R, Medina A, Mateo EM, Mateo F, Jiménez M. 2007. An overview of ochratoxin A in 3 beer and wine. Int J Food Microbiol. 119: 79-83.

4

5 Medina A, Jiménez M, Gimeno-Adelantado JV, Valle-Algarra FM, Mateo R. 2005. 6 Determination of ochratoxin A in beer marketed in Spain by liquid chromatography with 7 fluorescence detection using lead hydroxyacetate as a clean-up agent. J Chromatog A 1083: $87-13$.

9

10 Medina A, Valle-Algarra FM, Mateo R, Gimeno-Adelantado JV, Mateo F, Jiménez M. $2006 a$. 11 Survey of the mycobiota of Spanish malting barley and evaluation of the mycotoxin 12 producing potential of species of Alternaria, Aspergillus and Fusarium. Int J. Food Microbiol. 13 108: 196-203.

15 Medina A, Valle-Algarra FM, Gimeno-Adelantado JV, Mateo R, Mateo F, Jiménez M. 16 2006b. A new method for determination of ochratoxin A in beer using zinc acetate and SPE17 silica cartridges. J Chromatog A 1121: 178-183. 18

Moltó G, Samar MM, Resnik S, Martínez EJ, Pacin A. 2000. Occurrence of trichothecenes in 20 Argentinean beer A preliminary exposure assessment. Food Addit Cont. 17: 809-813.

22 Neira MS, Pacin A, Martínez EJ, Moltó G, Resnik SL. 1997. The effects of bakery processing 23 on natural deoxynivalenol contamination. Int J Food Microbiol. 37: 21-27.

Pacin A. 1992. Las micotoxinas como factor de riesgo en la salud humana. Santafe de Bogota 26 (Colombia): International Seminar Memories about Mycotoxins. Asociacion Colombiana de 27 Postcosecha de Granos, IDEMA, p. 87-108.

29 Pacin A, Resnik SL, Neira MS, Moltó G, Martínez EJ. 1997. Natural occurrence of 30 deoxynivalenol in wheat, wheat flour and bakery products in Argentina. Food Addit Cont. 14: 31 327-331. 
1 Osborne BG, Ibe FI, Brown GL, Patagine F, Scudamore KA, Banks JN, Hetmanski MT. 2 1996. The effects of milling and processing on wheat contaminated with ochratoxin A. Food 3 Addit Cont. 13: 141-153.

4

5 Quiroga N, Resnik SL, Pacin A, Martínez EJ, Pagano A, Riccobene I, Neira S. 1995. Natural

6 occurrence of trichothecenes and zearalenone in Argentine wheat. Food Control 6: 201-204. 7

8 Ragab WSM, Drusch S, Schnieder F, Beyer M. 2007. Fate of deoxynivalenol in contaminated 9 wheat grain during preparation of Egyptian "balila". Int J Food Sci Nutr. 58: 169-177.

10

11 Rotter BA, Prelusky DB, Pestka JJ. 1996. Toxicology of deoxynivalenol (vomitoxin). J Tox 12 Environ Health 48: 1-34.

14 Samar MM, Ferro-Fontán C, Resnik S, Pacin A, Castillo M. 2003. Distribution of 15 deoxynivalenol in wheat, wheat flour, bran, and gluten, and variability associated with the test 16 procedure. J AOAC Int. 86: 551-556.

Samar MM, Neira MS, Resnik SL, Pacin A. 2001. Effect of fermentation on naturally 19 occurring deoxynivalenol (DON) in Argentinean bread processing technology. Food Addit 20 Cont. 18: 1004-1010.

22 Samar M, Resnik SL, González HHL, Pacin AM, Castillo MD. 2007. Deoxynivalenol 23 reduction during the frying process of turnover pie covers. Food Control 18: 1295-1299.

25 Schollenberger M, Drochner W, Rüfle M, Suchy S, Terry-Jara H, Müller HM. 2005. 26 Trichothecene toxins in different groups of conventional and organic bread of the German 27 market. J Food Comp Anal. 18: 69-78.

29 Scientific Committee on Food. 1999. Opinion on Fusarium toxins, Part 1: Deoxynivalenol 30 (DON) expressed on 2 December 1999. European Commission SCF/CS/CNTM/MYC/19 31 Final. Available from http://europa.eu/comm/food/fs/sc/scf/out44_en.pdf 
1 Scientific Committee on Food. 2000. Opinion on Fusarium toxins. Part 4: Nivalenol 2 expressed on 19 October 2000. European Commission SCF/CS/CNTM/MYC/26 Final. 3 Available from http://europa.eu.int/comm/food/fs/sc/scf/out74_en.pdf 4

5 Scientific Committee on Food. 2002. Opinion of the Scientific Committee on Food on 6 Fusarium toxins. Part 6: Group evaluation of T-2 toxin, HT-2 toxin, nivalenol and 7 deoxynivalenol, adopted on 26 February 2002. European Commission 8 SCF/CS/CNTM/MYC/27 $\quad$ Final. $\quad$ Available from

9 http://europa.eu/comm/food/fs/sc/scf/out123_en.pdf

11 Scott PM, Kanhere SR, Lau PY, Dexter JE, Greenhalgh R. 1983. Effects of experimental 12 flour milling and breadbaking on retention of deoxynivalenol (vomitoxin) in hard red spring 13 wheat. Cereal Chem. 60: 421-424.

15 Scott PM, Kanhere SR, Dexter JE, Brennan PW, Trenholm HL. 1984. Distribution of the 16 trichothecene mycotoxin deoxynivalenol (vomitoxin) during the milling of naturally 17 contaminated hard red spring wheat and its fate in baked products. Food Addit Cont. 1: 31318323.

20 Scott PM. 1989. Trichothecene Mycotoxicosis: Pathophysiologic Effects. Boca Raton (USA): 21 Beasley VR; CRC Press. The natural occurrence of trichothecenes, p. 1-26.

Scott PM. 1991. Cereal grains. Mycotoxins. fungi and quality in drying and storage. Amsterdam (The Netherlands): Chelkowski J; Elsevier. Possibilities of reduction or elimination of mycotoxins present in cereal grains, p. 529-572.

Scott PM. 1996. Effects of processing and detoxification treatments on ochratoxin A: 28 introduction. Food Addit Cont. 13(suppl.): 19-22.

30 Scudamore KA. 1996. Ochratoxin A in animal feed - effects of processing. Food Addit Cont. 31 13(suppl.): 39-42.

33 Scudamore KA, Banks J, MacDonald SJ. 2003. Fate of ochratoxin A in the processing of whole wheat grains during milling and bread production. Food Addit Cont. 20: 1153-1163. 
1 Subirade I. 1996. Fate of ochratoxin A during breadmaking. Food Addit Cont. 13(suppl.): 25226.

3

4 Sugita-Konishi Y, Hara-Kudo Y, Kasuga F, Kumagai S. 1998. Effect of trichothecenes on 5 host defense against infectious diseases. Mycotoxins 47: 19-23.

6

Sugita-Konishi Y, Park BJ, Kobayashi-Hattori K, Tanaka T, Chonan T, Yosshikawa K, Kumagai S. 2006. Effect of cooking process on the deoxynivalenol content and its subsequent cytotoxicity in wheat products. Biosci Biotechnol Biochem. 70: 1764-1768.

Tanaka T, Hasegawa A, Yamamoto S, Matsuki Y, Ueno Y. 1986. Residues of Fusarium mycotoxins, nivalenol, deoxynivalenol and zearalenone, in wheat and processed food after milling and baking. Shokuhin Eiseigaku Zasshi 27: 653-655.

Trenholm HL, Charmley LL, Prelusky DB, Warner RM. 1991. Two physical methods for decontamination of four cereals contaminated with deoxynivalenol and zearalenone. J Agric Food Chem. 39: 356-360.

Tryphonas H, O’Grady L, Arnold DL, McGuire PF, Karpinski K, Vesonder RF. 1984. Effects of deoxynivalenol (vomitoxin) on the humoral immunity of mice. Tox Lett. 23: 17-24.

Ueno Y. 1983. Trichothecenes: Chemical, Biological and Toxicological Aspects. Elsevier Scientific Publishers. Amsterdam (The Netherlands). p. 314.

Valero A, Farré JR, Sanchis V, Ramos AJ, Marín S. 2006. Effects of fungal interaction on ochratoxin A production by $A$. carbonarius at different temperatures and $a_{w}$. Int $J$ Food Microbiol. 110: 160-164.

Valle-Algarra FM, Medina A, Gimeno-Adelantado JV, Llorens A, Jiménez M, Mateo R. 2005. Comparative assessment of solid-phase extraction clean-up procedures, GC columns and perfluoroacylation reagents for determination of type B trichothecenes in wheat by GCECD. Talanta 66: 194-201.

Vicam LP. 1999. OchraTest instruction manual. Watertown, (MA, USA). Vicam LP Int. 
1 WHO. 1998. Food Safety Unit, Programme of Food Safety and Food Aid: Regional per capita

2 consumption of raw and semi-processed agricultural commodities. WHO/FSF/FOS/98.3

3

4 Young LC, Subryan LM, Potts D, McLaren ME, Gobran FH. 1986. Reduction in levels of

5 deoxynivalenol in contaminated wheat by chemical and physical treatment. J Agric Food 6 Chem. 34: 659-664.

7

8 Young LC. 1986. Reduction in levels of deoxynivalenol in contaminated corn by chemical 9 and physical treatment. J Agric Food Chem. 34: 665-667.

10

11 Yumbe-Guevara BE, Yoshizawa T. 2003. Reduction of deoxynivalenol and nivalenol content 12 during roasting of naturally contaminated barley. Mycotoxins 53: 87-93. 13

14 Westby A, Reilly A, Bainbridge Z. 1997. Review of the effect of fermentation on naturally 15 occurring toxins. Food Control 8: 329-339. 


\section{Figure captions}

2

3

$$
4
$$

9 Figure 2.- Average reduction percentages and standard deviations of (a) OTA, (b) DON, (c) 10 NIV and (d) 3-ADON during the baking stage at different temperature/time combinations 11 (190 ${ }^{\circ} \mathrm{C} / 50 \mathrm{~min}, 207^{\circ} \mathrm{C} / 40 \mathrm{~min}, 223^{\circ} \mathrm{C} / 35 \mathrm{~min}$ and $240{ }^{\circ} \mathrm{C} / 30 \mathrm{~min}$ ). Spiking levels (in $\mathrm{\mu g} \mathrm{kg}^{-1}$ 12 wheat flour) OTA: 2, 5, and 10; DON and 3-ADON: 200, 750, and 1500; NIV: 200, 500, and 13 1000. Experiments were performed in triplicate. 14 15 Figure 3.- Average reduction percentages and standard deviations of (a) OTA, (b) DON, (c) 16 NIV, and (d) 3-ADON at the inside and the outside parts of the bread during the baking stage 17 at $190{ }^{\circ} \mathrm{C} / 50 \mathrm{~min}, 207^{\circ} \mathrm{C} / 40 \mathrm{~min}, 223^{\circ} \mathrm{C} / 35 \mathrm{~min}$ and $240{ }^{\circ} \mathrm{C} / 30 \mathrm{~min}$. Spiking levels (in $\mu \mathrm{g} \mathrm{kg}^{-}$ $18{ }^{1}$ wheat flour) OTA: 2, 5, and 10; DON and 3-ADON: 200, 750, and 1500; NIV: 200, 500, 19 and 1000. Experiments were performed in triplicate. 


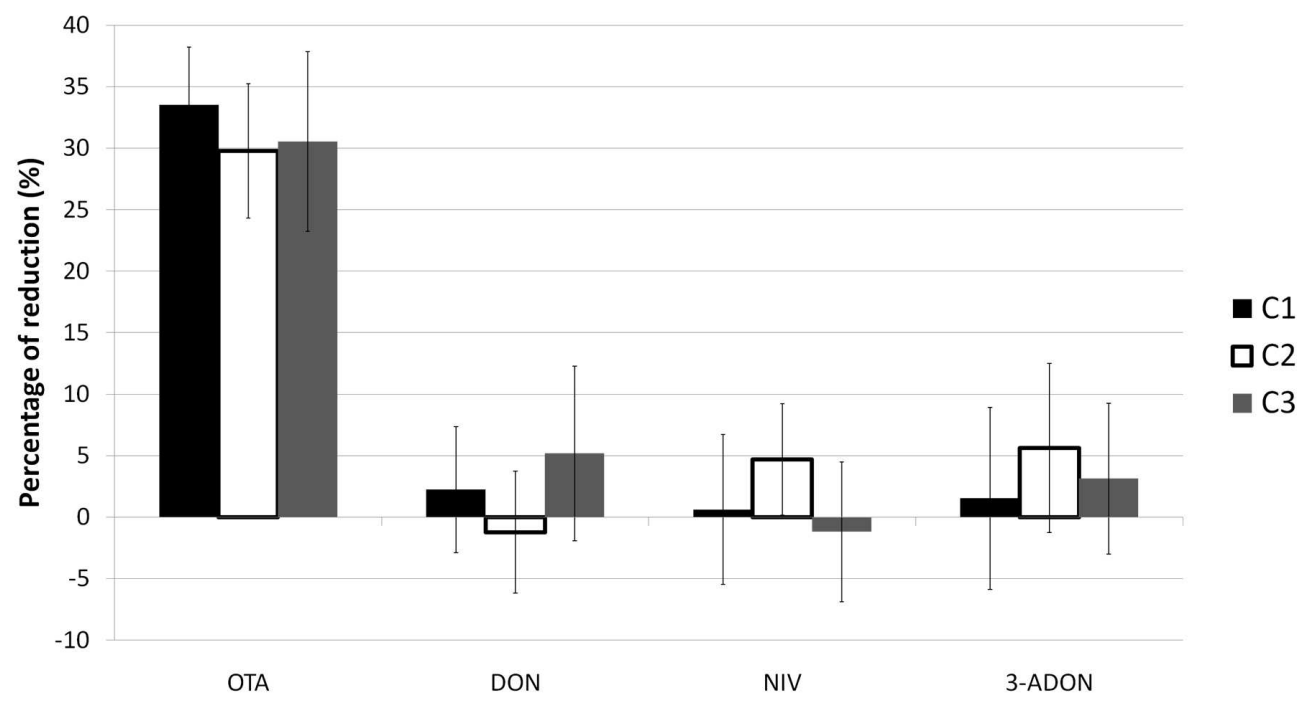

Figure 1.Âl Average reduction percentages and standard deviations of OTA, DON, 3Â̄ ADON and NIV during dough fermentation at $30^{\circ} \mathrm{C}$ for 60 min. Spiking levels (in $\mu g \mathrm{kgÂ} \square 1$ wheat flour): (C1) 200 for each DON, NIV and 3Â̄ ADON and 2 for OTA; (C2): 750 for each DON and 3Ẫ ADON, 500 for NIV, and 5 for OTA; (C3): 1500 for each DON and 3Ẫ ADON, 1000 for NIV and 10 for OTA. Experiments were performed in triplicate. $479 \times 259 \mathrm{~mm}(96 \times 96 \mathrm{DPI})$ 
Figure 2.Âl] Average reduction percentages and standard deviations of (a) OTA, (b) DON, (c) NIV and (d) $3 \hat{A} \square$ ADON during the baking stage at different temperature/time combinations $\left(190^{\circ} \mathrm{C} / 50\right.$ $\min , 207^{\circ} \mathrm{C} / 40 \mathrm{~min}, 223^{\circ} \mathrm{C} / 35 \mathrm{~min}$ and $2400^{\circ} \mathrm{C} / 30 \mathrm{~min}$ ). Spiking levels (in $\mu \mathrm{g} \mathrm{kg} \hat{A} \square 1$ wheat flour) OTA: 2, 5, and 10; DON and 3ÂA ADON: 200, 750, and 1500; NIV: 200, 500, and 1000.

Experiments were performed in triplicate. $478 \times 896 \mathrm{~mm}(87 \times 87 \mathrm{DPI})$ 

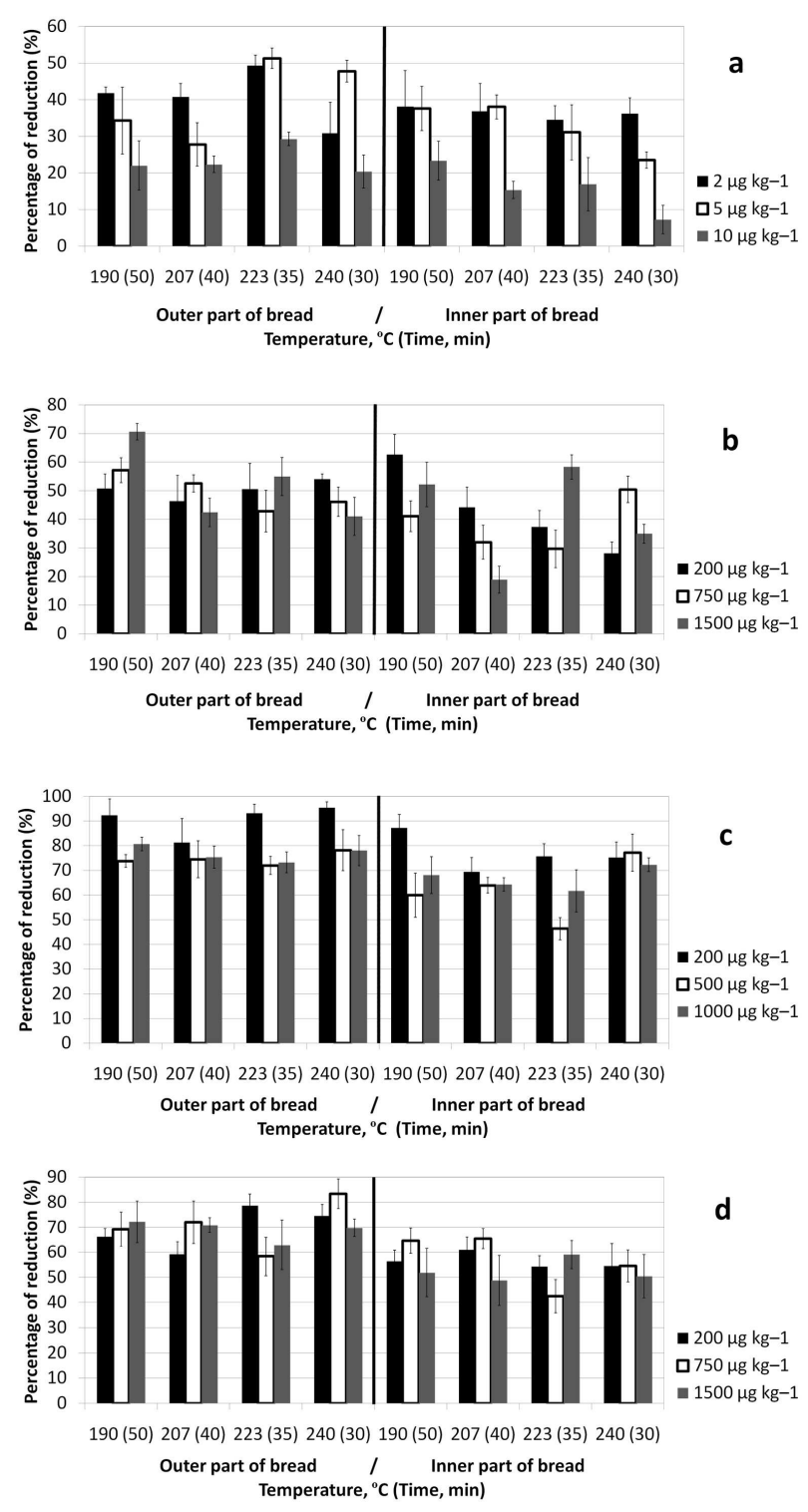

Figure 3.Âl Average reduction percentages and standard deviations of (a) OTA, (b) DON, (c) NIV, and (d) $3 \hat{A} \square$ ADON at the inside and the outside parts of the bread during the baking stage at 190 ${ }^{\circ} \mathrm{C} / 50 \mathrm{~min}, 207^{\circ} \mathrm{C} / 40 \mathrm{~min}, 223^{\circ} \mathrm{C} / 35 \mathrm{~min}$ and $240^{\circ} \mathrm{C} / 30 \mathrm{~min}$. Spiking levels (in $\mu \mathrm{g} \mathrm{kgÂ} \square 1$ wheat flour) OTA: 2, 5, and 10; DON and 3Â̄ ADON: 200, 750, and 1500; NIV: 200, 500, and 1000.

Experiments were performed in triplicate. $478 \times 896 \mathrm{~mm}(87 \times 87 \mathrm{DPI})$ 